\title{
Report of dental care experience, preventive and restorative, in a riverside community
}

\author{
Relato de experiência de atendimento odontológico, preventivo e \\ restaurador, em uma comunidade ribeirinha
}

Regiane Cristina do Amaral'1, Dirceu Alves Carvalho², Jáder Lima Barbosa1', Glaucy Passos Sakai

${ }^{1}$ Curso de Odontologia, Centro Universitário Doutor Leão Sampaio (UNILEÃO) - Juazeiro do Norte (CE), Brasil.

${ }^{2}$ Curso de Odontologia, Centro Universitário UniEvangelica - Anápolis (GO), Brasil

${ }^{3}$ Curso de Enfermagem, UniEvangelica - Anápolis (GO), Brasil

DOI: http://dx.doi.org/10.7322/abcshs.v43i2.989

\begin{abstract}
Introduction: Dental caries, despite having declined in recent years, presents groups considered polarized with highest rate of the disease, among other reasons due to the lack of access to health services. Experience report: Description of a dental care experience (preventive, educational and restorative) in children aged 0 to 15 years in a riverside community in the state of Pará. The first visit to the community (February 2014) lasted 3 days and was carried out as an epidemiological survey according to World Health Organization criteria. Educational and preventive activities besides dental treatments were provided to this community. At the second visit (February 2015), again with duration of three days, oral health from this community was reevaluated. Data from the two analyzed periods, distant one year between each analysis, were compared. A total of 34 children aged 1 to 6 years according to the dmft index and 54 children/adolescents aged 7 to 15 years according to the dmft/ DMFT index were examined. Statistically significant differences were found in aspects: caries $(p=0.03)$, missing teeth $(p=0.04)$, and filled teeth $(p=0.01)$. Conclusion: Access to health services associated with educational and preventive activities showed positive results in the visited riverside community.
\end{abstract}

Keywords: dental caries; education, dental; oral health.

\section{RESUMO}

Introdução: A cárie dentária, apesar de ter tido declínio nos últimos anos, apresenta grupos considerados polarizados nos quais detém os maiores valores da doença, entre outros devido à falta de acesso a serviços de saúde. Relato de experiência: Descrição de uma experiência de atendimento odontológico (preventivo, educativo e restaurador) em crianças/adolescentes de 0 a 15 anos em uma comunidade ribeirinha do Pará. A primeira visita à comunidade (Fevereiro de 2014) teve duração de três dias e foi um levantamento epidemiológico seguindo critérios da Organização Mundial de Saúde. Foram ainda realizadas atividades educativas e preventivas, além de tratamentos odontológicos nesta comunidade. Na segunda visita (Fevereiro de 2015), novamente com duração de três dias, a condição de saúde bucal desta comunidade foi reavaliada. Os dados dos dois períodos analisados, distando um ano entre cada análise, foram comparados. Foram examinadas 34 crianças de 1 a 6 anos de acordo com o índice ceod e 54 crianças/adolescentes de 7 a 15 anos de acordo com o índice ceod/CPOD. Foi encontrada diferença estatisticamente significante nos aspectos dentes cariados $(p=0,03)$, perdidos $(p=0,04)$ e obturados $(p=0,01)$. Conclusão: $O$ acesso aos serviços de saúde associado a atividades educativas e preventivas demonstrou resultados positivos na comunidade ribeirinha visitada.

Palavra-chave: cárie dentária; educação em odontologia; saúde bucal.

Recebido em: 20/06/2017

Revisado em: 18/01/2018

Aprovado em: 23/02/2018

Autor para correspondência: Regiane Cristina do Amaral - Centro Universitário Dr. Leão Sampaio - Avenida Maria Letícia Leite Pereira s/n - Lagoa Seca CEP: 63040-405 - Juazeiro do Norte - (CE) - E-mail: amaralre@yahoo.com.br

Conflito de interesses: nada a declarar 


\section{INTRODUCTION}

Dental caries is one of the most prevalent chronic conditions in childhood. About $50 \%$ of preschool children in different countries have caries experience ${ }^{1}$. This estimate is also available in studies conducted in Brazil, where prevalence rates range from $20.3 \%^{2}$ to $53.6 \%{ }^{3}$, with inequalities seen especially among poor population groups ${ }^{4}$.

In Brazil differences between regions are observed. The North and Northeast regions often denote discrepancies when comparing oral health indices. According to the second report of the SB Brazil - 2010, the average values of Decayed, Missing, and Filled Teeth (DMFT) index for the age of 5 years are higher in the North, Midwest and Northeast compared to the South and Southeast regions. Moreover, the proportion of decayed teeth is significantly higher in the North and Northeast, while the restored teeth are higher in the South and Southeast. In relation to the DMFT index these data are similar to the ages of 12 and 15 to 19 years for periodontal disease. The highest percentage of children age 12 with healthy sextants was found in the Southeast (67.9\%) and lowest in the North $(41.6 \%)^{5}$.

There are also discrepancies between urban and rural regions, and the worst oral health conditions are found in countryside. This is most likely due to the difficulty of access to health services, which make the principle of "universality" and "completeness" of the Brazilian Unified Health System (SUS) are not always reached".

Among these disadvantaged groups, riverside groups are an important example. Due to difficult access to large urban centers or because of seasonal specific factors restricting access (for example, periods with dry or shallow river where is impossible for large boats to have access to communities), these communities have inadequate assistance to health. In many cases when assistance is available the treatments are largely curative. Preventive and educative measures that may change habits are left aside. Health education is a process that, through communication, seeks to transfer knowledge and skills to people ensuring that they can make right choices about their health ${ }^{6}$.

Against with this situation and the absence of studies that portray the epidemiological profile of oral health of these populations, as well as the characterization of supply and access to dental services ${ }^{7}$.

This study aims to report of experience of a preventive, educational and restorative dental care provided to a riverside community located in the Alto Arapiuns region, Pará State, Brazil, during the period of 1 year.

\section{EXPERIENCE REPORT}

The study included one community (Prainha do Maró) which is located in Pará State, approximately $120 \mathrm{~km}$ southwest of the city of Santarém (straight), called Prainha. This community is located on the Maró river, from the tributary system of the Arapiuns river.

\section{Community characteristics studied}

This community is a benchmark for other communities. This community relies on the presence of community health agent, nursing technicians and health center, provided by the government. Local elementary school provides education up to the fourth year of primary level. The teachers are from major cities and they remain in the community during the school period.

The mobility of this community to the nearest city (Santarém Pará) in urgent cases is through the inland waterway transport, taking 18 to 20 hours by boat. Thus, due to the difficulty of reaching this community, health services are scarce.

This community still has a power generator, which is on for a period of 4 hours a day. As a food base, the population in general plants manioc and manufactures manioc flour, and feeds on fruits and animals found in the forest surrounding the community. Furthermore, there is a boat going to the community once a week to sell products including candies, sweets, gasoline and meat.

\section{Study Design}

The study was first conducted in 2014. The team responsible for the study visited the community and talked to community leaders and school teachers to learn about local habits, if the children were brushing their teeth and if there were some pain episodes. In this moment an epidemiological survey was realized the toothbrush, fluoride toothpaste and dental floss were distributed. In this occasion, dental treatment and education in oral health was also provided. After that, every 3 month the team visited again the community to distribute toothbrush, fluoride toothpaste and dental floss and to talk with the teachers about the education in oral health.

One year after the start of the study (2015), an epidemiological survey was held again to verify the effectiveness of the intervention.

Each community visit lasted three days. On the first day an epidemiological survey was carried out. On the second and third days educational and preventive activities were carried out, as well as dental treatment.

The dentists responsible for examinations were previously trained for the local conditions. Ten percent of the sample was examined and reviewed to obtain the intra observer error, with the percentage concordance index ranging from 0.86 to 1 for the caries experience (DMFT) and kappa statistic of 0.95 .

Parents and/or guardians signed the consent form (Protocol 007/2013) allowing that the children/adolescents to participate in the study. The sample included all children aged 1-15 years old (88 individuals) who agreed to participate in the study or who were in the community on day of the study.

To evaluate dental caries $\mathrm{dmft}$ and DMFT were used (decayed, missing, filled teeth, permanent or deciduous) and treatment needs according to the WHO criteria ${ }^{8}$.

Preventive activities were delivered: toothbrushes, fluoride toothpastes, dental floss and a glass to individualize the dental hygiene kit. The researchers teach how important it is the individual use of these kits, so that they would not agglomerate toothbrushes and would avoid contamination among family members.

To educational and preventive activities puppets, dummy dental records, drawings, educational video (via PowerPoint) were 
used. Tooth brushing supervision was accompanied by parents. Topical application of acidulated phosphate fluoride (ATF) was provided according to the caries risk.

The dental treatments were performed by four dentists according to necessity. All activities in the community had the participation of parents, in order to ensure their reliability. This study tried to emphasize health education, prioritizing non-invasive care such as ART (atraumatic restorative treatment).

People living in the community in many cases have never been to the dentist. In relation to children and adolescents examined, they had contact with a dentist for the first time through this team, except for a few teenagers, in which contact with the dentist was mostly in the city of Santarém-PA for tooth extraction.

The data obtained in this study were entered in an Excel spreadsheet. Statistical test (Student $\mathrm{t}$ test paired), comparing the first moment and the second moment (visit), was performed using SPSS 17.0 software. The variable studied was dental caries about DMFT index before and after one year of the time.

\section{Results}

The data were compared to the two analyzed the local condition a year after the first visit. Thirty four children aged 1 to 6 years were examined according to the $\mathrm{dmft}$ index (decayed, missing, filled teeth). Statistical difference in relation to decayed teeth, $(\mathrm{p}=0.03)$ and filled teeth $(\mathrm{p}=0.01)$ were found (Figure 1$)$.

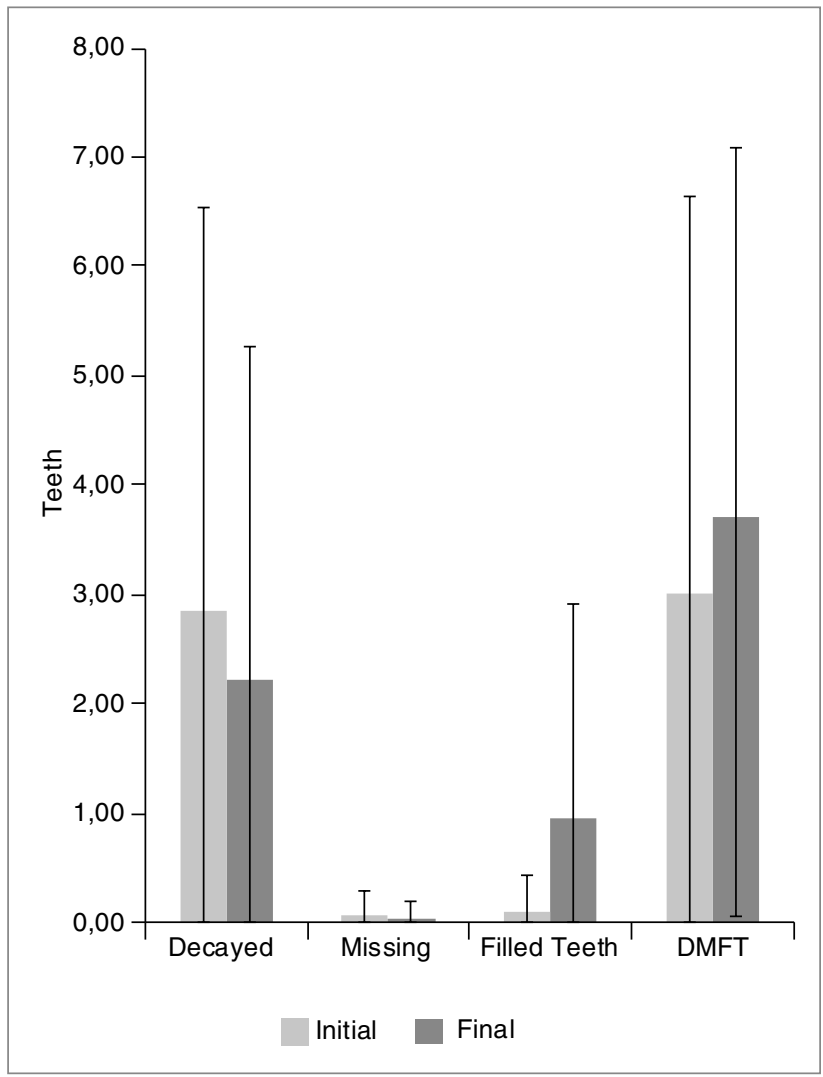

Figure 1: Mean and standard deviation of the dmft index of children/ adolescents 1-6 years at initial and final of study. Pará - Brazil, 2015.
Fifty four children/adolescents aged 7-15 years were examined, according to the DMFT (decayed, missing, filled teeth). Statistically significant difference between the carious teeth ( $p=0.03$ ) between the element missing $(\mathrm{p}=0.04)$ and filled element without cavities $(\mathrm{p}=0.01)$ (Figure 2).

\section{DISCUSSION}

In order to ensure care within the national oral health policies, an increased access to health services is proposed ${ }^{9}$ using offices in river transport, trucks, among others.

There are some boats trying to assist the riverside population in Pará. Among them there is Abare ${ }^{10}$ boat in which medical care is offered to the population. However, these boats are large and, in some locations with shallow rivers, they cannot reach the communities.

Unlike the boats that provide health care, there are small trade boats that sell products from Santarém-PA to the riverside population, like fuel, sugar, biscuits, candies, etc. It is quite common in these communities that parents or teachers justify that many children cannot go to school because they have toothache. Children and adolescents have eaten products with sugar and generally don't brush their teeth.

Some people seek assistance in Santarém-PA (nearest city), only when they have pain, and in many cases the treatment is the

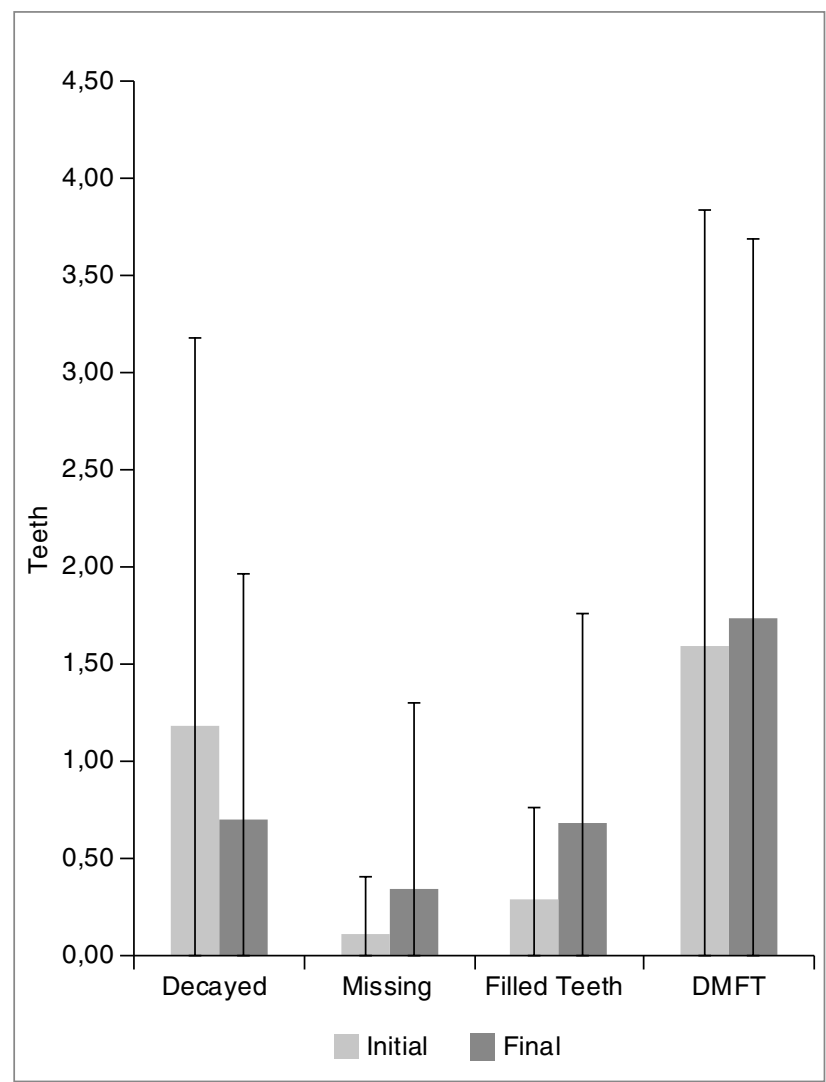

Figure 2: Mean and standard deviation of the DMFT index of children/ adolescents 7-15 years at initial and final of study. Pará - Brazil, 2015. 
tooth extraction, to be faster, since there will be no continuity of care due to distance.

According to these conditions, the present study has sought beyond the treatment to offer educational and preventive activities and evaluate their impact in the period of 1 year. Thirty-four children aged 1 to 6 years were examined according to the DMFT index and 54 children/adolescents 7-15 years, with the DMFT. As this is a community where children/adolescents had the first contact with the dentist through this project, this index is characterized mainly by carious element.

The purpose of the study was characterized by changing of habits, since children/adolescent should brush the teeth more frequently. However, it would be impossible such a change if the parents or guardians were not involved, as reported in some studies $^{11}$. In the present study because of the distance, when the boat comes to the community, everybody is involved in the research, participating in the activities. It is observed during every 3 month visits that teachers and parents participate in the health promotion process, distribution of oral health care kits, guiding children to perform better oral hygiene after main meals.

It was also reported by teachers that no children have given up their activities because of a toothache. It was also observed that the carious element was decreased in the final phase of the study, which was statistically significant.

Access to health services associated with educational and preventive activities has shown positive results in riverside community visited.

\section{REFERENCES}

1. Baelum V, van Palenstein Helderman W, Hugoson A, Yee R, Fejerskov O. A global perspective on changes in the burden of caries and periodontitis: implications for dentistry. J Oral Rehabil. 2007;34(12):872-906.

http://dx.doi.org/10.1111/j.1365-2842.2007.01799.x

2. Abanto J, Tsakos G, Paiva SM, Carvalho TS, Raggio DP, Bönecker M. Impact of dental caries and trauma on quality of life among 5- to 6-year-old children: perceptions of parents and children. Community Dent Oral Epidemiol. 2014;42(5):385-94

http://dx.doi.org/10.1111/cdoe.12099

3. Corrêa-Faria P, Martins-Júnior PA, Vieira-Andrade RG, Marques LS, Ramos-Jorge ML. Factors associated with the development of early childhood caries among Brazilian preschoolers. Braz Oral Res. 2013:27(4):356-62. http://dx.doi.org/10.1590/S1806-83242013005000021

4. Costa SM, Abreu MHNG, Vasconcelos M, Lima RCGS, Verdi M, Ferreira EF. Desigualdades na distribuição da cárie dentária no Brasil: uma abordagem bioética. Ciênc Saúde Coletiva. 2013;18(2):461-70. http://dx.doi.org/10.1590/S1413-81232013000200017

5. Brasil. Ministério da Saúde. Projeto SB Brasil 2010. Resultados parciais. Disponível em: http://189.28.128.100/dab/docs/geral/ apresentacao_SB2010.pdf. Acesso em: 10 fev. 2016.
6. Machado MFAS, Vieira NFC, Silva RM. Compreensão das mudanças comportamentais do usuário no programa saúde da família por meio da participação habilitadora. Ciênc Saúde Coletiva. 2010;15(4):2.133-43.

7. Cohen-Carneiro F, Souza-Santos R, Pontes DG, Salino AV, Rebelo MAB. Oferta e utilização de serviços de saúde bucal no Amazonas, Brasil: estudo de caso em população ribeirinha do Município de Coari. Cad Saúde Pública. 2009;25(8): 1827-38.

http://dx.doi.org/10.1590/S0102-311X2009000800019

8. World Health Organization. Oral health surveys, basic methods. Geneva: WHO; 1997.

9. Brasil. Ministério da Saúde. Secretaria de Atenção à Saúde. Departamento de Atenção Básica. Coordenação Nacional de Saúde Bucal. Diretrizes da Política Nacional de Saúde bucal. Brasília: Ministério da Saúde; 2004.

10. Franco EC, Santo CE, Arakawa AM, Xavier A, França ML, Oliveira $\mathrm{AN}$, et al. Promoção da saúde da população ribeirinha da região Amazônica: relato de experiência. Rev CEFAC. 2015;17(5):1521-30. http://dx.doi.org/10.1590/1982-0216201517518714

11. Castilho AR, Mialhe FL, Barbosa TS, Puppin-Rontani RM. Influence of family environment on children's oral health: a systematic review. J Pediatr. 2013;89(2):116-23.

http://dx.doi.org/10.1016/j.jped.2013.03.014 